\title{
KANDUNGAN ANTIOKSIDAN DAUN MAHANG DAMAR (Macaranga triloba (BI.) Muell Arg.)
}

\author{
Pienyani Rosawanti ${ }^{1)}$, Dewi Sari Mulia2), Syahrida Dian Ardhany) \\ ${ }^{1}$ Fakultas Pertanian dan Kehutanan, Universitas Muhammadiyah Palangkaraya \\ email:pienyani@yahoo.com \\ ${ }^{2}$ Fakultas IImu Kesehatan, Universitas Muhammadiyah Palangkaraya \\ email: dewisarimulia@gmail.com \\ ${ }^{3}$ Fakultas IImu Kesehatan, Universitas Muhammadiyah Palangkaraya \\ email: chass501@gmail.com
}

\begin{abstract}
ABSTRAK
In the year 2015, the plants that initially grow a lot of wild is increasing in popularity because many contested by the citizens. The reason is because the plant has an economic value. Based on the literature review it is known that apigenin, a flavonoid compound has been isolated from the ethyl acetate fraction of methanolic extract of Macaranga gigantia leaf. Compounds that have potential as antioxidants are generally compounds of flavonoids, phenolics, and alkaloids. Flavonoid and polyphenolic compounds are antioxidant, antidiabetic, anticancer, antiseptic, and anti-inflammatory, while alkaloids have antineoplastic properties that also inhibit the growth of cancer cells. Phenol content, antioxidant activity and antibacterial activity were also found in Macaranga gigantea, M. hosei, M. hypoleuca, M. kingii, M. pruinosa and M. triloba (Lim et.al., 2014). This leads to the notion that mahang leaves were obtained and collected from the Central Kalimantan region where this study carried out also contained similar content and activity. Determination of the value of antioxidant activity in this study using DPPH method performed on $n$-hexane extract ofmahang leaf obtained by maceration. $\mathrm{N}$-hexane extract of mahang leaf have antioxidant activity, this can be seen from the preliminary TLC test results where the spots produced when sprayed with DPPH fluoresce when viewed at $366 \mathrm{~nm}$ uv. The average value of $I C_{50} \mathrm{n}$ hexane extract of mahang leaves was 141.3 ppm.
\end{abstract}

Keywords: antioksidan, daun mahang damar, Macaranga triloba

\section{PENDAHULUAN}

Tahun 2015 yang lalu tersiar kabar mengenai popularitas pohon mahang damar atau Macaranga triloba (BI.) Muell Arg. di daerah Hulu Sungai Tengah, Kalimantan Selatan.Tanaman yang awalnya banyak tumbuh liar ini meningkat popularitasnya karena banyak diperebutkan oleh warga.Alasannya adalah karena tanaman tersebut memiliki nilai ekonomis.Daun Mahang Damar atau oleh warga setempat disebut daun sepat dikumpulkan untuk dijual kembali dengan harga yang relatif tinggi.
Mahang damar merupakan pohon berukuran sedang dengan tinggi dapat mencapai $35 \mathrm{~m}$ dan diameternya dapat mencapai $70 \mathrm{~cm}$. Batang bebas cabangnya dapat mencapai 25 meter, berbentuk bulat, halus, berwarna agak abu-abu kehijauan, dan kadang-kadang berbanir tetapi kecil. Kulit luarnya agak tebal, berdaging tipis yang berwarna agak kuning keputihan, dan agak lekat.Tajuk pohon berbangun seperti payung, yang melebar di bagian atas.Daun tersusun tunggal, bercaping tiga, lemas, 
permukaan daun bagian atas dan bawah berwarna hijau, tetapi permukaan daun bawah lebih kasar dan agak berbulu halus.Bunga jantan dan betina terpisah, yang jantan berukuran relatif lebih kecil daripada bunga betina.Bunga kecil warna kuning, tersusun dalam malai.Buah kotak yang terbagi dalam tiga ruang, berukuran kecil dan keras. Mahang damar umumnya tumbuh di hutan sekunder tua (belukar tua), daerah padang terbuka, dan hutan primer yang dibuka. Jenis ini merupakan salah satu jenis pionir yang berhasil baik, serta berbunga dan berbuahnya sepanjang tahun. Tumbuhan ini sangat menyukai daerah dengan tanah berpasir putih atau kuning, lepas dan agak berliat.

Berdasarkan kajian literatur diketahui bahwa apigenin, senyawa flavonoid telah diisolasi dari fraksi etil asetat ekstrak metanol daun Macaranga gigantia.Isolasi dan pemurnian apigenin dilakukan dengan menggunakan kolom dan kromatografi sentrifugal dan struktur kimia dicirikan berdasarkan data spektroskopi. Dalam uji aktivitas antikanker secara in vitro terhadap garis sel leukimia P-388 menunjukkan aktivitas berpotensi sebagai antikanker dengan IC50 14,13 $\mu \mathrm{g} / \mathrm{ml}$. Penelitian serupa mengenai daun mahang yang dilakukan oleh Megawati dkk (2015) menunjukkan bahwa 5,7,3', $4^{\prime}$ tetrahidroksi-6-geranilflavonol dan kaemferol 7-O- $\beta$-glukosa merupakan dua senyawa flavonoid yang diisolasi dari daun Macaranga hispida(Blume) Mull.Arg.
Kandungan senyawa metabolit sekunder pada ekstrak total dan ekstrak fraksi n-heksana dari daun mahang (Macaranga pruinosa (M.) M. A.) adalah alkaloid dan steroid. Fraksi etil asetat mengandung senyawa steroid. Fraksi etanol-air mengandung senyawa alkaloid dan fenolik. Senyawa yang mempunyai potensi sebagai antioksidan umumnya merupakan senyawa flavonoid, fenolat, dan alkaloid. Senyawa flavonoid dan polifenolat bersifat antioksidan, antidiabetik, antikanker, antiseptik, dan antiinflamasi, sedangkan alkaloid mempunyai sifat antineoplastik yang juga ampuh menghambat pertumbuhan sel kanker. Kandungan fenol, aktivitas antioksidan dan aktivitias antibakteria ditemukan juga pada daun Macaranga gigantea, M. hosei, M. hypoleuca, $M$. kingii, M. pruinosa dan M. triloba (Lim et.al., 2014). Hal ini mengarahkan pada pemikiran bahwa daun mahang yang diperoleh dan dikumpulkan dari daerah setempat dimana penelitian ini dilakukan juga memiliki kandungan dan aktivitas serupa.

Antioksidan adalah molekul yang mampu menghambat oksidasi molekul yang dapat menghasilkan radikal bebas. Radikal bebas adalah suatu senyawa atom atau molekul yang mengandung satu atau lebih elektron tidak berpasangan. Adanya elektron yang tidak berpasangan menyebabkan senyawa tersebut sangat reaktif mencari pasangan, dengan cara menyerang dan mengikat 
elektron molekul yang berada disekitarnya. Radikal bebas sangat berbahaya dikarenakan tingginya reaktivitasnya yang mengakibatkan terbentuknya senyawa radikal baru. Bila senyawa radikal baru tersebut bertemu dengan molekul lain, maka akan terbentuk radikal baru lagi dan seterusnya hingga terjadi reaksi berantai.

Radikal bebas dapat mengganggu integritas sel dan dapat bereaksi dengan komponen-komponen sel, baik komponen struktural meliputi molekul-molekul penyusun membran maupun komponen fungsional meliputi protein, enzim-enzim, dan DNA. Radikal bebas dapat dijumpai pada lingkungan, beberapa logam misalnya besi dan tembaga, asap rokok, polusi udara, obat, bahan beracun, makanan dalam kemasan, bahan aditif, dan sinar ultraviolet matahari yang menyebabkan radiasi. Reaktifitas radikal bebas itu dapat dihambat oleh sistem antioksidan yang merupakan bagian dari sistem kekebalan tubuh (Winarsi, 2007).

Berdasarkan latar belakang tersebut dapat dirumuskan permasalahan yang ada apakah daun mahang damar memiliki kandungan metabolit sekunder yang berkhasiat sebagai antioksidan.Lingkup penelitian ini hanya difokuskan pada pengkajian kandungan bioaktif daun mahang damar dan aktivitasnya.Penelitian tentang daun mahang damar belum banyak diteliti di Kalimantan Tengah padahal informasi ini sangat bermanfaat dalam pemanfaatan daun mahang sebagai tanaman yang berkhasiat sebagai sumber obat.Oleh karena itu penelitian ini dilakukan untuk mengkaji kandungan senyawa metabolit sekunder yang terkandung dalam daun mahang.Kandungan dan informasi senyawa metabolik sekunder diharapkan dapat berperan dalam pengembangan tanaman obat yang bermanfaat bagi kesehatan.

\section{METODE PENELITIAN}

\section{Waktu dan Tempat Penelitian}

Penelitian dilakukan di Laboratorium Penelitian Fakultas IImu Kesehatan Universitas Muhammadiyah Palangkaraya selama bulan Mei - Oktober 2017.

\section{Alat}

Alat yang digunakan pada penelitian ini adalah blender, peralatan maserasi, cawan penguap, penguap vakum putar (rotary evaporator), labu erlenmeyer, tabung reaksi, labu takar, gelas ukur, penampung berbagai ukuran, pipet volume, pipet mikro (Eppendorf), pipet tetes (Pyrex), corong Buchner (Jangkar), spektrofotometer UV-VIS, kuvet, plat tetes, gelas arloji, rak tabung reaksi, batang pengaduk, spatel, sendok tanduk, timbangan analitik, bejana kromatografi, kertas saring, peralatan kolom kromatografi vakum, vortex-mixer, inkubator $37^{\circ} \mathrm{C}$ dan lemari pendingin. 


\section{Bahan Uji}

Bahan uji yang digunakan dalam penelitian ini daun Macaranga triloba (BI.) Muell Arg. yang diperoleh dan dikumpulkan dari daerah Palangka Raya Kalimantan Tengahdan dideterminasi di Fakultas Biologi Universitas Palangka Raya.

\section{Bahan Kimia}

Bahan kimia yang digunakan pada penelitian ini adalah n-heksanyang telah didestilasi; metanol p.a; lempeng KLT; butanol; asam asetat; aqua; H2SO410 \% sebagai penampak noda pada KLT; silika gel asam klorida p.a (Merck); asam sulfat p.a; (Merck); benzene p.a (Merck); asam asetat anhidrat; asam borat; asam oksalat; besi (III) klorida; etanol $96 \%$; natrium hidroksida; serbuk magnesium; serbuk seng; gelatin; natrium klorida; Mayer LP; Dragendorff LP; Bouchardat LP; Molisch LP; DPPH (Sigma-Aldrich). Bahan pembanding adalah Kuersetin (SigmaAldrich).

\section{Penyiapan Bahan}

Tanaman yang digunakan diperoleh dari pengumpul di daerah Palangka Raya Kalimantan Tengah. Bagian yang digunakan dalam penelitian ini adalah daun yang telah dikeringkan di bawah sinar matahari langsung setelah melalui proses penimbangan, sortasi, dan pencucian. Pengeringan dilakukan bertujuan untuk mendapatkan simplisia yang tidak mudah rusak oleh adanya pertumbuhan jamur sehingga dapat disimpan dalam waktu yang lebih lama. Dengan mengurangi kadar air dan menghentikan reaksi enzimatik dapat mencegah penurunan mutu atau perusakan simplisia. Setelah diperoleh simplisia dalam bentuk kering, proses selanjutnya adalah penghalusan dan pengayakan yang bertujuan untuk memperoleh serbuk yang homogen dan mempermudah dalam proses penarikan zat aktif pada saat ekstraksi berlangsung. Serbuk yang telah halus selanjutnya disimpan dalam wadah tertutup baik dan terlindung dari cahaya untuk menjaga mutu simplisia.

\section{Pembuatan Ekstrak}

Maserasi dilakukan pada serbuk simplisia menggunakan pelarut $n$ heksan.Maserasi dilakukan sampai filtrat terlihat hampir tidak berwarna (dilakukan pengulangan maserasi sampai lima kali) lalu filtrat yang diperoleh dikumpulkan dan dievaporasi dengan rotary evaporator(pada suhu $50^{\circ} \mathrm{C}$ ) sehingga diperoleh ekstrak n-heksan kental yang masih dapat dituang, lalu ekstrak dikeringkan pada suhu kamar. Proses maserasi menggunakan kurang lebih 5 liter pelarut dengan pengocokan selama 6 jam dan didiamkan selama 18 jam setelah pengocokan.

a. Uji Pendahuluan Aktivitas Antioksidan Ekstrak dengan Metode KLT (Isnindar dkk, 2011) 
b. Uji Aktivitas Antioksidan Ekstrak (Blois, 1958).

c. Optimasi Panjang Gelombang DPPH

d. Pembuatan Larutan Blanko

e. Pembuatan Larutan Kuersetin sebagai Pembanding

f. Pengukuran Serapan Sampel

g. Perhitungan

Persentase inhibisi $\left(\mathrm{IC}_{50}\right)$ terhadap radikal $\mathrm{DPPH}$ dari masing-masing konsentrasi larutan sampel dapat dihitung dengan rumus:

\%inhibisi=

$\frac{\text { absorban blanko-absorban sampel }}{\text { absorban blanko }} \times 100 \%$

h. Identifikasi Alkaloid (Wagner et al.,1984)

i. Identifikasi flavonoid (Depkes RI, 1995 dan Wagner et al., 1984)

\section{HASIL DAN PEMBAHASAN}

Hasil

Tabel 1. Identifikasi Kimia

\begin{tabular}{ccccc}
\hline $\begin{array}{c}\text { Kompone } \\
\mathbf{n}\end{array}$ & Pereaksi & Acuan & Pengamatan & Hasil \\
\hline & & Ektrak n- Heksan & & \\
Alkaloid & Dragendorff & $\begin{array}{c}\text { Terbentuk endapan } \\
\text { merah bata }\end{array}$ & $\begin{array}{c}\text { Terbentuk endapan } \\
\text { merah bata }\end{array}$ & + \\
Flavonoid & Pb Asetat & Hijau kehitaman & Hijau kehitaman & + \\
\hline
\end{tabular}

Tabel 2. Hasil Pengamatan $I_{50}$ Ekstrak Heksan (Replikasi 1)

\begin{tabular}{cccccc}
\hline $\begin{array}{c}\text { Kadar } \\
(\mathbf{p p m})\end{array}$ & $\begin{array}{c}\text { Absorbsi } \\
\text { Blanko (Ab) }\end{array}$ & $\begin{array}{c}\text { Absorbsi } \\
\text { Sampel (As) }\end{array}$ & Ab-As & $\begin{array}{c}\text { (Ab-As) } \\
\text { /Ab }\end{array}$ & \% Inhibisi \\
\hline 40 & 0,872 & 0,69 & 0,182 & 0,2087 & 20,87 \\
60 & 0,872 & 0,663 & 0,209 & 0,2397 & 23,97 \\
80 & 0,872 & 0,594 & 0,278 & 0,3188 & 31,88 \\
100 & 0,872 & 0,547 & 0,325 & 0,3727 & 37,27 \\
\hline
\end{tabular}

$y=b x+a$

$y=0,2856 x+8,5092(r=0,9879)$

IC ${ }_{50}$ Ekstrak Heksan I:

$50=0,2856 x+8,5092$

$\mathrm{x}=145,3 \mathrm{ppm}$

Tabel 3. Hasil Pengamatan $I_{50}$ Ekstrak Heksan (Replikasi 2)

\begin{tabular}{|c|c|c|c|c|c|}
\hline $\begin{array}{l}\text { Kadar } \\
(\mathrm{ppm})\end{array}$ & $\begin{array}{c}\text { Absorbsi } \\
\text { Blanko (Ab) }\end{array}$ & $\begin{array}{c}\text { Absorbsi } \\
\text { Sampel (As) }\end{array}$ & Ab-As & $\begin{array}{c}\text { (Ab-As) } \\
/ A b\end{array}$ & $\%$ Inhibis \\
\hline 40 & 0,872 & 0,736 & 0,136 & 0,156 & 15,60 \\
\hline 60 & 0,872 & 0,664 & 0,208 & 0,2385 & 23,85 \\
\hline 80 & 0,872 & 0,609 & 0,263 & 0,3016 & 30,16 \\
\hline 100 & 0,872 & 0,552 & 0,32 & 0,367 & 36,70 \\
\hline $\begin{array}{l}=b x+a \\
=0,3481 \\
S_{50} \text { Ekstra } \\
0=0,348 \\
=137,3\end{array}$ & $\begin{array}{l}2133(r=0, \\
\text { ksan II: } \\
2,2133\end{array}$ & & & & \\
\hline
\end{tabular}


Tabel 4. Hasil Pengamatan $I_{50}$ Kuorsetin sebagai Pembanding

\begin{tabular}{cccccc}
\hline $\begin{array}{c}\text { Kadar } \\
(\mathbf{p p m})\end{array}$ & $\begin{array}{c}\text { Absorbsi } \\
\text { Blanko }(\mathbf{A b})\end{array}$ & $\begin{array}{c}\text { Absorbsi } \\
\text { Sampel }(\mathbf{A s})\end{array}$ & Ab-As & $\begin{array}{c}\text { (Ab-As) } \\
\text { /Ab }\end{array}$ & \% Inhibisi \\
\hline 2 & 1,101 & 0,892 & 0,209 & 0,1898 & 18,98 \\
3 & 1,101 & 0,758 & 0,343 & 0,3115 & 31,15 \\
4 & 1,101 & 0,626 & 0,475 & 0,4314 & 43,14 \\
5 & 1,101 & 0,467 & 0,634 & 0,5758 & 57,58 \\
6 & 1,101 & 0,331 & 0,77 & 0,6994 & 69,94 \\
\hline
\end{tabular}

$\mathrm{y}=\mathrm{bx}+\mathrm{a}$

$y=12,834 x-7,1753(r=0,9995)$

IC 50 Kuersetin:

$50=12,834 x-7,1753$

$\mathrm{x}=4,46 \mathrm{ppm}$

Tabel 5. Hasil Pengamatan KLT dengan DPPH

\section{PERLAKUAN}

KLT ekstrak daun mahang:

Ekstrak $n$-heksana

Fase diam:

Silika gel $60 \mathrm{~F}_{254}$ for thin layer

chromatography

Fase gerak: Kloroform

Pereaksi semprot DPPH

Penampakan secara visual HASIL DOKUMENTASI

Rf ekstrak $n$ heksana
a) $0,4 / 5,5=0,073$
b) $0,8 / 5,5=0,145$

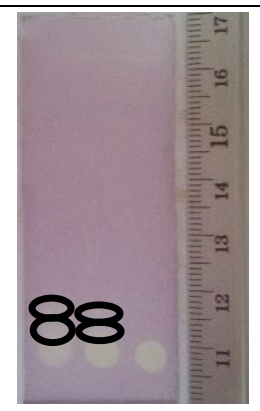

123

\section{PEMBAHASAN}

Tanaman yang digunakan pada penelitian ini adalah daun mahang damar (Macaranga triloba (BI.) Muell Arg.) yang diperoleh di daerah desa lahei Kalimantan Tengah. Daun mahang damar yang diperoleh kemudian dikeringkan dibawah sinar matahari langsung, kemudian dibuat serbuk dengan cara diblender. Pengeringan bertujuan untuk mendapatkan simplisia yang tidak mudah rusak oleh adanya pertumbuhan jamur sehingga dapat disimpan dalam waktu yang lebih lama. Dengan mengurangi kadar air dan menghentikan reaksi enzimatik untuk mencegah penurunan mutu atau perusakan simplisia.

Penghalusan dan penyaringan ditujukan untuk memperoleh serbuk yang homogen dan untuk mempermudah proses penarikan zat aktif pada saat ekstraksi. Serbuk yang telah kering selanjutnya disimpan dalam wadah bersih, kering dan terlindung dari cahaya untuk mencegah kerusakan dan mutu simplisia tetap terjaga. Serbuk kering daun mahang damar (Macaranga triloba (BI.) Muell Arg.) ditimbang sebanyak 50 gram kemudian dimaseraasi samapi jernih dengan pelarut $n$ - heksan selama 3 hari. Filtrat yang diperoleh dipekatkan dengan rotary evaporator.

Pelarut yang digunakan adalah $n$ heksan yang bersifat non-polar dengan tujuan untuk menghilangkan lemak dan mengekstraksi senyawa-senyawa yang 
bersifat non-polar seperti asam lemak, sterol kumarin dan beberapa terpenoid.

Uji pendahuluan bertujuan untuk mengetahui ada tidaknya senyawa aktif di dalam ekstrak yang memiliki aktivitas antioksidan dalam meredam radikal bebas (DPPH). Ekstrak ditototolkan pada lempeng silika gel $60 \quad F_{254}$ dengan menggunakan mikropipet, di elusi mengunakan fase gerak kloroform.

Uji selanjutnya dilakukan dengan penyemprotan larutan DPPH. Setelah disemprot dengan larutan $\mathrm{DPPH}$, uji aktivitas antioksidan secara kualitatif menunjukan hasil positif yang ditandai dengan pengamatan UV dengan menggunakan panjang gelombang 366 nm menghasilkan noda bercak yang berpendar, dengan latar belakang berwarna ungu. Namun Rf yang dihasilkan kurang optimal sehingga zat aktif tidak terpisah secara sempurna.

Penentuan nilai aktivitas antioksidan pada penelitian ini menggunakan metode DPPH. Metode uji aktivitas antioksidan dengan DPPH (2,2-difenil-1-pikrilhidrazil) dipilih karena metode ini adalah metode sederhana, mudah, cepat dan peka serta hanya memerlukan sedikit sampel untuk evaluasi aktivitas antioksidan dari senyawa bahan alam sehingga digunakan secara luas untuk menguji kemampuan senyawa yang berperan sebagai pendonor elektron atau hidrogen. Pengujian aktivitas antioksidan ekstrak daun mahang damar (Macaranga triloba (BI.) Muell Arg.)pada penelitian ini menggunakan metode DPPH yang telah digunakan oleh Molyneux dengan sedikit modifikasi (Molyneux, 2004).

Prinsip dari metode uji aktivitas antioksidan ini adalah pengukuran aktivitas antioksidan secara kuantitatif yaitu dengan melakukan pengukuran penangkapan radikal DPPH oleh suatu senyawa yang mempunyai aktivitas antioksidan dengan menggunakan spektrofotometri UV-Vis sehingga dengan demikian akan diketahui nilai aktivitas peredaman radikal bebas yang dinyatakan dengan nilai $\quad \mathrm{IC}_{50} \quad$ (Inhibitory Concentration).

Tahap awal pengukuran diawali dengan pembuatan larutan DPPH. Larutan berwarna ungu gelap, larutan harus disimpan dalam wadah yang terlindung dari sinar matahari untuk mencegah dekomposisi. Tahap selanjutnya yang dilakukan adalah pengukuran panjang gelombang maksimum ( $\lambda_{\text {maks }}$ ) yang mana di dapatkan panjang gelombang $516 \mathrm{~nm}$, larutan DPPH digunakan sebagai blanko. Blanko berfungsi untuk melihat konsentrasi radikal bebas dari larutan DPPH sebelum penambahan senyawa uji dimana nilai absorbansinya digunakan sebagai faktor pengurang dari lartan DPPH yang telah ditambahkan senyawa uji sehingga didapat nilai \% inhibisi. 

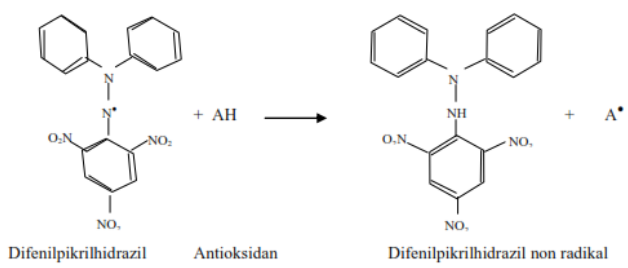

Gambar 2. Reaksi Peredaman DPPH

dengan senyawa antioksidan (Molyneux, 2004)

Tahap selanjutnya adalah pembuatan larutan induk sampel dari ekstrak daun mahang damar, larutan sampel induk yang dibuat kemudian diencerkan dengan variasi seri kadar. Tujuan dari pembuatan variasi kadar ini bertujuan untuk memberi gambaran mengenai aktivitas antioksidandari senyawa uji. Setelah penambahan senyawa uji ke dalam larutan $\mathrm{DPPH}$, terjadi penurunan absorbansi DPPH dibandingkan dengan blanko. Menurut hukum LambertBeer, ada korelasi sebanding antara konsentrasi dengan absorbansi, jika terjadi penurunan konsentrasi maka absorbansi spektrum sinar dari larutan tersebut juga akan mengalami penurunan. Turunnya absorbansi menandakan berkurangnya konsentrasi radikal bebas dari DPPH.Berkurangnya konsentrasi radikal bebas dari DPPH dikarenakan adanya reaksi dengan senyawa antioksidan yang mengakibatkan molekul DPPH tereduksi dan diikuti dengan berkurangnya intensitas warna ungu dari larutan DPPH.

Nilai $I_{50}$ ekstrak $n$-heksan daun mahang damar didapat dari hasil perhitungan persamaan regresi linier, dilakukan sebanyak 2 kali replikasi, persamaan regresi dari ekstrak $n$-heksan daun mahang damar adalah $y=0,2856 x+$ $8,5092(r=0,9879)$ dan $y=0,3481 x+$ $2,2133$ ( $r=0,9980)$. Koefisien y pada persamaan ini adalah sebagai $I_{50}$, sedangkan koefisien $\mathrm{x}$ pada persamaan ini adalah konsentrasi dari ekstrak yang akan dicari nilainya, dimana nilai dari $x$ yang didapat merupakan besarnya konsentrasi yang diperlukan untuk dapat meredam 50\% aktivitas radikal DPPH. Nilai $r$ yang mendekati +1 (bernilai positif) menggambarkan bahwa dengan meningkatnya konsentrasi ekstrak maka semakin besar aktivitas antioksidannya.

Nilai $I_{50}$ rata-rata ekstrak $n$-heksan daun mahang damar adalah 141,3 ppm. Suatu zat mempunyai sifat antioksidan kuat apabila nilai $\mathrm{IC}_{50}$ berkisar anatar 50 100 ppm, dimana zat tersebut berpotensi sebagai zat antioksidan (Molyneux, 2004). Kontrol positif yang digunakan pada penelitian ini adalah kuersetin dimana didapatkan $\quad \mathrm{IC}_{50}$ sebesar 4,46 ppm.Penggunaan kontrol positif pada pengujian aktivitas antioksidan ini adalah untuk mengetahui seberapa kuat potensi antioksidan yang ada pada masingmasing ekstrak daun mahang damar jika dibandingkan dengan kuersetin. Apabila nilai $I_{50}$ sampel sama atau mendekati nilai $I_{50}$ kontrol posititf maka dapat dikatakan bahwa sampel berpotensi sebagai salah satu alternatif antioksidan yang sangat kuat. 


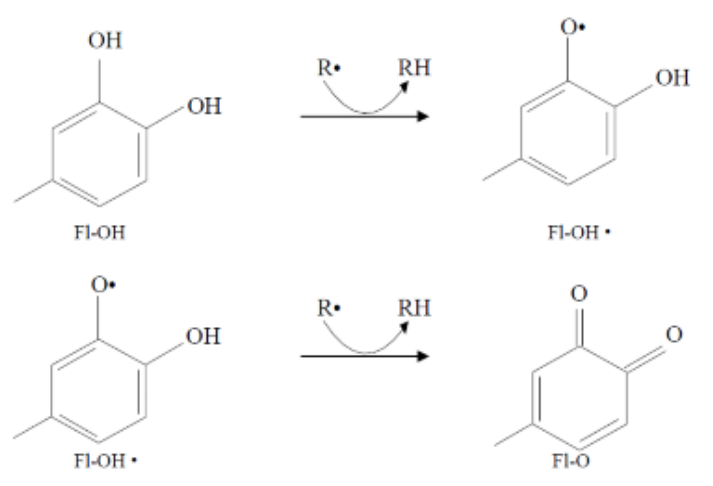

Gambar 3. Mekanisme Peredaman

Radikal oleh Flavonoid (Kandaswani dan

Middleton, 1997)

Berdasarkan uji kualitatif ekstrak daun mahang damar, didapatkan bahwa ekstrak positif alkaloid dan flavonoid. Golongan senyawa yang diduga berpotensi sebagai antioksidan adalah flavonoid. Flavonoid merupakan senyawa pereduksi yang dapat menghambat banyak reaksi oksidasi. Flavonoid memiliki kemampuan sebagai antioksidan karena mampu mentransfer sebuah elektron kepada senayawa radikal bebas, dimana $\mathrm{R}^{\star}$ merupakan senyawa radikal bebas, $\mathrm{FI}$ $\mathrm{OH}$ merupakan senyawa flavonoid sedangkan $\mathrm{FI}-\mathrm{OH}^{*}$ merupakan radikal flavonoid (Kandaswani dan Middleton, 1997).

\section{KESIMPULAN}

Ekstrak $n$-heksan daun mahang damar memiliki aktivitas antioksidan, hal ini dapat dilihat dari hasil uji pendahuluan secara KLT dimana bercak yang dihasilkan ketika disemprot dengan DPPH berpendar ketika dilihat pada uv $366 \mathrm{~nm}$. Nilai rata-rata $\mathrm{IC}_{50}$ ekstrak $n$-heksan daun mahang damar adalah 141,3 ppm.
Sedangkan nilai $\mathrm{IC}_{50}$ kuersetin sebagai pembanding adalah 4,46 ppm. Jadi dapat disimpulkan bahwa ekstrak $n$-heksan daun mahang damar memiliki aktivitas antioksidan yang lemah jika dibandingkan dengan kuersetin.

\section{DAFTAR PUSTAKA}

Blois, M.S. (1958). Antioxidant Determinations By The Use Of $A$ Stable Free Radical Nature, 181, 1199- 1200.

Departemen Kesehatan Republik Indonesia.(1995). Materia Medika Indonesiajilid VI. Jakarta: Departemen Kesehatan Republik Indonesia.

Isnindar., Setyowat, E.P., dan Wahyuono, S. (2011). Aktivitas Antioksidan Daun Kesemek (Diospyros kaki L.F) Dengan Metode DPPH (2,2DifenilPikrilhidrazin). Majalah Obat tradisional.

Kandaswami, C dan Middleton, E (1997), Flavonoids as antioxidant, In F. Shahidi (Ed). Natural Antioxidant Chemistry, Health Effects and Applications. Champaign Illions: AOCS Press.

Lim T.Y., Lim Y.Y., dan Yule C.M. 2014.Bioactivity of leaves of Macaranga species in tropical peat swamp and non-peat swamp environments. Journal of Tropical Forest Science 26(1): 134-141.

Megawati, Saepudin E., Hanafi M., Darmawan A., dan Dewi N. L.P. 2015. Identification and Bioactivity Studies of Flavonoid Compounds from Macaranga hispida (Blume) Mull.Arg. Makara J. Sci. 19( 3):96100 doi: $10.7454 / \mathrm{mss} . v 19 i 3.4848$

Molyneux, P. (2004). The Use of The Stable Free Radical Diphenyl Picrylhydrazil (DPPH) for Estimating Antioxidant Activity. Songklankarin J. Sci. Technol., 26 (2), 211-219.

Wagner, $\quad H$. Blandt, S., dan Zgalnski.(1984). Plant Drug Analysis. New York:SpringerVerlag, 7-304. 
Kandungan Antioksidan Daun Mahang Damar (Macaranga triloba (BI.) Muell Arg.)

Winarsi, H. (2007). Antioksidan Alami dan

Radikal Bebas. Yogyakarta:

Kanisius. 